Instructions for authors, subscriptions and further details:

http://remie.hipatiapress.com

\title{
The Communication Skills of Future Teachers during their Initial Training
}

Antonio Rodríguez Fuentes ${ }^{1}$, María Fernanda Ayllón Blanco², José Luis Gallego Ortega ${ }^{1}$ \& Isabel Angustias Gómez Pérez ${ }^{2}$

1) Universidad de Granada, Spain.

2) Escuela Universitaria la Inmaculada, Spain.

Date of publication: February $15^{\text {th }}, 2017$

Edition period: February 2017-June 2017

To cite this article: Rodríguez Fuentes A., Ayllón Blanco, M. F., Gallego Ortega, J. L., \& Gómez Pérez, I. A. (2017). The Communication Skills of Future Teachers during their Initial Training. Multidisciplinary Journal of Educational Research, 7(1), 88-118. doi:10.17583/remie.2017.2200

To link this article: http://dx.doi.org/10.17583/remie.2017.2200

\section{PLEASE SCROLL DOWN FOR ARTICLE}

The terms and conditions of use are related to the Open Journal System and to Creative Commons Attribution License (CC-BY). 


\section{The Communication Skills of Future Teachers during their Initial Training}

Antonio Rodríguez Fuentes

Universidad de Granada

José Luis Gallego Ortega

Universidad de Granada
María F. Ayllón Blanco

E.U. La Inmaculada

Isabel A. Gómez Pérez

E.U. La Inmaculada

\section{Abstract}

Communication skills are considered vital in order to work as a professional teacher. This study evaluates the communication skills of students in teaching programs at two public universities of Spain. We developed a questionnaire based on consolidated theoretical knowledge in the field of educational communication: a) skills as a transmitter, b) skills as a receiver, c) skills as a classroom teacher, d) skills as a participant in meetings, and e) skills as a tutor; and gave it to 670 students who were in their first (start of their degree), second (middle of their degree) and third years (about to graduate) of a teaching degree in the academic year 2013/2014, so that the data reflected the participants' levels of experience. Through the use of cross-cutting research methods we obtained the data and performed quantitative analyses of a descriptive nature. The results revealed a certain inadequacy in the acquisition and development of teaching-related communication skills, which was more pronounced in supposedly "classical" areas of communication: transmission and reception than in others: classroom communication, meeting participation and tutorial conversation, despite the fact that more progress is made in the former areas over time. We discuss these data and offer guidelines for specific training.

Keywords: communication skills, educational communication, initial teacher training, teaching-related communication; teaching skills 


\section{Competencia Comunicativa de los Futuros Docentes durante su Formación Inicial}

Antonio Rodríguez Fuentes

Universidad de Granada

José Luis Gallego Ortega

Universidad de Granada

\author{
María F. Ayllón Blanco \\ E.U. La Inmaculada \\ Isabel A. Gómez Pérez \\ E.U. La Inmaculada
}

\section{Resumen}

Las competencias comunicativas se consideran imprescindibles para el desempeño profesional docente. En este estudio se valora el grado de dominio que poseen estudiantes de Magisterio de dos universidades públicas españolas, con motivo de apreciar su desarrollo. Para ello, se empleó un cuestionario cuyas dimensiones derivan del conocimiento teórico consolidado en el campo de la comunicación educativa: a) competencia como emisor; b) competencia como receptor, c) competencia como comunicador en el aula, d) competencia comunicativa como participante en reuniones, e) competencia como tutor; y se aplicó a 670 estudiantes de primero, segundo y tercer nivel de la carrera de Magisterio durante el curso académico 2012/14. Mediante un diseño transversal de investigación, se obtuvieron los datos y se realizaron análisis cuantitativos de tipo descriptivo. Los resultados arrojan cierta timidez en la adquisición y desarrollo de las habilidades comunicativas docentes, más acusada en las dimensiones supuestamente clásicas del acto comunicativo (emisor y receptor) que en otras (comunicador en el aula, participante en reuniones y conversador en tutorías), pese a que son en las primeras en las que más se progresa con el transcurso de los años. Se discuten estos datos y se proporcionan orientaciones para una formación específica en educomunicación.

Palabras clave: competencia comunicativa, formación inicial del profesorado, comunicación docente, competencias docentes 
7 he final report of the World Conference on Higher Education (UNESCO, 1998) underlined the importance of higher education to the social, cultural and economic development of society and detailed the main challenges faced at this level, including improving the quality of teaching and skills-based training. As indicated by Aznar and Ull (2009), skills-oriented training forms part of the framework of educational reform for universities driven by European convergence guidelines. The study of professional skills in higher education has now become a necessary field. The prospect of overcoming the traditional "encyclopedic" approach has encouraged Spanish universities, within the context of the European Higher Education Area (EHEA), to focus on skills when designing new study plans for the training of future teachers. As various authors have affirmed (Álvarez, Asensio \& García, 2013; Capitani \& Felicetti, 2016; López, 2011), this requires the parallel development of techniques and instruments for self-evaluation (questionnaires, checklists, portfolios, interviews, etc.) in order to assess the level reached by the students.

It has been argued that the notion of "skills" - which is analogous to others such as capacities, competences and abilities - has invaded the educational field and imposed itself upon the professional and trainingrelated world, with the general aim of identifying repertoires of actions that are learned within their context and give people the ability to resolve issues in a given situation (Álvarez, 2010, p. 35). In this context, special importance is given to the development of technical competences with a professional focus, particularly communication skills, in accordance with the White Paper issued by the National Agency for Quality Assessment and Accreditation (ANECA, 2005), the Spanish Framework of Qualifications for Higher Education (Government of Spain, 2009), Royal Decree 1393/2007 (Official State Gazette (BOE) of 30 October) establishing the regulations governing official university education in Spain, and Order $\mathrm{ECI} / 3857 / 2007$ (BOE of 30 December) establishing the requirements for verification of official university qualifications for the teaching profession (Davies \& Taras, 2016). The latter stipulates the achievement of Level C1 competence in Spanish, which, in accordance with the Common European Framework of Reference for Languages (CEFR) (Consejo de Europa, 2002), equates to the effective functional mastery expected of a competent language user. 


\section{REMIE-Multidisciplinary Journal of Educational Research, 7(1) 91}

In the international context, various studies and texts also emphasize the importance of communication skills in the teaching profession (e.g. Danielson, 2011; Comisión Europea, 2008; Consejo de Europa, 2006; Gauthier, 2006; Government of Chile, 2008; ITE, 2000; Martinet, Raymond \& Gauthier, 2004; TDA, 2007). Training in communication skills aims to develop productive, multi-functional people who are capable of responding to the new educational, scientific and technological challenges that require such abilities (Amara, Karavdic \& Baumann, 2013; Corredor, 2011; Pérez \& Gonçalves, 2013).

Ultimately, communication skills are part of every list that is drawn up by universities, from Cambridge (Transferable skills for undergraduate students 1998-2003) to Canada (Grayson, 1999) to demonstrate the professional profile of their graduates. In a sense, teaching is perceived as a multi-directional communicative process, meaning communicative exchange is the foundation upon which knowledge is constructed (Mérida, 2013). Thus, in the words of Perrenoud (2004), communication skills are a basic initial competence for teachers; a competence upon which their professional success depends to a significant extent and which the higher education process must guarantee in order to help develop efficient professional training that meets the needs and demands of teaching in the European environment (Scottish Office, 2005).

However, the concept of communicative competence has evolved and been transformed, in a similar way to the concept of language itself, so that, rather than being understood as a system of decontextualized units, it is perceived as an instrument of communication that should be studied from the perspective of its use (Aguilar, 2010). For the CEFR, communication skills encompass linguistic skills, sociolinguistic skills and pragmatic skills, which in turn encompass other sub-skills, knowledge areas, capacities and abilities, all of which explains the difficulty of mastering these skills and the need to focus on this area in order to train competent teaching professionals.

However, for the purposes of this study, communication skills are understood as the series of processes and knowledge areas that combine in order to produce or comprehend discourse that is appropriate for the communicative context and situation at hand and the level of formality required (Lomas, Osorio \& Tusón, 1993, p. 15). Thus, communication 


\section{Rodríguez et al. - Communication Skills of Future Teachers}

skills refer to a person's ability to address another clearly, coherently and effectively. Consequently, these skills should manifest themselves through individual ability and be developed through the mastery of knowledge (theoretical understanding), doing (skills and abilities), being (willingness or attitude) and wanting to do (motivation), within a given social, cultural, spatial and temporal context (Bermúdez \& González, 2011).

Therefore, students of teaching must correctly learn their own language (spoken and written) from both a normative and communicative perspective, and be able to manage their classroom, communicate appropriately with their future students and facilitate the latter's acquisition of communicative aptitudes, competences and practical knowledge (Camargo \& Pardo, 2008, p. 447). This is especially important when the teacher-student relationship and teaching-learning process are being modified in order to promote an alternative educational approach that focuses more on learning and skills than teaching and knowledge, where the teacher is more of a mediator and it is the student who constructs his or her own lifelong learning process (Gutiérrez \& de Pablos, 2010; Paredes \& Inciarte, 2013).

However, numerous voices have alerted us to the expressive difficulties experienced by many students and their inability to express themselves fluidly and precisely in their own language, whether spoken or written (e.g. Corredor \& Romero, 2008; Corredor, 2011; Gallego, García \& Rodríguez, 2013). Some authors even argue that many teachers have difficulty communicating or expressing themselves (Camacho \& Sáenz, 2000), despite the fact that teachers are communicators whose success directly depends on their ability to communicate attitudes, values and ideas (Ferreiro, 2011).

Based on the foregoing, our research problem was formulated as follows: Do university students in the Early Childhood Education (ECE) and Primary Education (PE) programs possess the necessary communication skills to adequately perform the role of teacher?

In line with the above, our study perceptive objectives were: 1) to discover how future ECE and PE teachers perceive their training in communication skills; 2) to analyze any progress their communication skills underwent during their degree; 3 ) to compare any differences between students from two different Spanish universities; 4) to analyze any 
differences between ECE and PE students; 5) to identify any gender-related differences in the field of communication; and 6) to propose strategies for optimizing these skills during initial training.

\section{Methodology}

For this quantitative study we adopted an empirical-analytical approach and a cross-cutting, non-experimental design. The sample was randomly chosen, as the students completed the self-evaluation questionnaire in their own free time.

\section{Sample}

The study was conducted at two public institutions of higher education in the Autonomous Region of Andalusia, Spain; namely, the universities of Cordoba (UCO) and Seville (USE). Students were selected from levels 1 (start of their degree), 2 (middle of their degree) and 3 (about to graduate), so that the data reflected the participants' levels of experience.

A total of 670 students from both universities took part (292 from UCO and 378 from USE), who were studying ECE and PE. Their ages ranged from 18 to 38 [ $(\overline{\boldsymbol{x}}=20.53 ; \mathrm{SD}=1.915)$, UCO $(\overline{\boldsymbol{x}}=20.30 ; \mathrm{SD}=1.739)$, USE $(\overline{\boldsymbol{x}}$ $=20.71 ; \mathrm{SD}=2.025)]$.

Table 1 (Annex A) details the contribution of each university to the sample, broken down by level, program and gender.

\section{Instrument}

To measure the students' perception of their own communication skills we used a questionnaire that had already been used in other studies (Domingo et al., 2010; Gallego \& Rodríguez, 2013, 2015). We used a Likert-type scale (no mastery [1], insufficient mastery [2], sufficient mastery [3], elevated mastery [4] and exceptional mastery [5]) for the answers to the questionnaire, which comprised 60 questions and was divided, in accordance with the bibliography consulted (e.g. AGAEVE, 2010; Camacho \& Sáenz, 2000; Castellá et al., 2007; Martinet et al., 2004), into 5 sections or areas, as follows: 


\section{Rodríguez et al. - Communication Skills of Future Teachers}

1. Skill as a transmitter of interpersonal communication (12 questions). This area refers to the set of knowledge, skills and abilities required to be a good, efficient transmitter of information.

2. Skill as a receiver in the communicative process (10 questions). This section asked students about the knowledge, skills and abilities required to receive, interpret and utilize (manage) messages and draw inferences from them.

3. Classroom communication skills (20 questions). This section examined the different communication skills the future teachers will need in the classroom (pronunciation, organization and structure of discourse, use of appropriate lexicon, motivational strategies, etc.)

4. Communication skills for participating in meetings with parents or colleagues (12 questions). Communication skills are not only important for teaching activities, but also for successfully participating in meetings with parents or colleagues. The students were questioned about these skills.

5. Communication skills for tutoring (6 questions). Finally, students were specifically asked about communication skills for fostering the processes of empathy, trust and intercommunication that are required for successful tutoring.

The questionnaire was validated using the expert judgement procedure (Fox, 1981), with the experts in question unanimously validating it. Its reliability and internal consistency were also statistically tested. The questionnaire obtained an alpha reliability coefficient of 0.936 , while the reliability coefficient of the questions analyzed ranged from 0.935 to 0.936 . We also applied Guttman's split-half test, the results of which demonstrate the high level of reliability: $\left(\alpha 1^{\text {st }}\right.$ part $=0.900, \alpha 2^{\text {nd }}$ part $=0.881$; Spearman-Brown coefficient: 0.866), along with a KMO (significance of 0.91 , very close to 1 ) and Bartlett test (chi-square of 19313.955 and very high significance, $\mathrm{p}=0.000$ ).

The overall internal consistency of the questionnaire in terms of size and scale was as follows: $1^{\text {st }}(0.80), 2^{\text {nd }}(0.83), 3^{\text {rd }}(0.97), 4^{\text {th }}(0.90), 5^{\text {th }}(0.88)$.

\section{Procedures}


We utilized so-called "questionnaire-based social research" (McMillan \& Schumacher, 2005) to obtain data from the students' written statements regarding their communication skills.

The data was gathered at the end of the 2013-2014 academic year, on different days and at different times that were convenient for the students in light of the voluntary nature of their participation. They were informed of the purpose of the study, guaranteed anonymity in order to encourage truthful responses, and thanked for their collaboration.

Finally, their responses were collated, ordered and recorded in a database for statistical analysis.

\section{Data Analysis}

The quantitative data was analyzed using the SPSS 22.0 program. Frequencies and percentages were obtained in order to describe the independent socio-demographic variables (gender, university, program and level). Distribution by gender was analyzed using contingency tables and chi-square tests.

The scores on the scale were assigned by calculating the mean value for the questions per student, thereby obtaining a central value. These scalerelated variables were described using the mean $(\overline{\boldsymbol{x}})$, standard deviation (SD), median, maximum and minimums. The confidence intervals (CI) were set at $95 \%$ from the mean.

To analyze the relationship between the independent variables and the communication scales, we used linear regression models and multivariate analysis of variance (MANOVA), in light of the existence of more than one interrelated dependent variable (Steven, 2002). We checked the graphical normality of the scales using Q-Q plots (thus eliminating the need to perform the Kolmogorov-Smirnov data normality test) and chose MANOVA and Pillai's trace $(V$ ) given their greater robustness and capacity to detect real differences in the event of deviation in the mathematical supposition of an equal covariance matrix (Field, 2005). For the chosen statistical modeling process, we adjusted all the independent variables in an initial model, which we used in order to progressively eliminate the nonsignificant independent variables and their interactions. We ensured that the model had been adjusted correctly by analyzing its residual normality and 


\section{Rodríguez et al. - Communication Skills of Future Teachers}

mean goodness of fit. We then compared the effect of the independent variables on the scales to a significance level of $5 \%$.

\section{Results}

To better understand the data we should note that there were gender-based differences in distribution per level; i.e., there was a smaller percentage of males in the upper levels than in the lower, where the percentage of females is higher (chi-square=7.153; $\mathrm{df}=2 ; \mathrm{p}$-value=0.029). However, the distribution of students by gender and level at USE was similar (chisquare $=2.478 ; \mathrm{df}=2 ; \mathrm{p}$-value $=0.29$ ).

In terms of level, there were no gender-based differences in either specialty (ECE: chi-square=2.834; $\mathrm{df}=2 ; \mathrm{p}$-value=0.274; $\mathrm{PE}$ : chisquare $=5.668 ; \mathrm{df}=2 ; \mathrm{p}$-value=0.06). Nor, generally, were there genderbased differences in level, as the distribution was similar for males and females (chi-square $=5.885 ; \mathrm{df}=2 ; \mathrm{p}$-value $=0.058$ ).

However, we did identify gender-based differences between specialties, with a smaller percentage of males studying ECE compared to PE (chisquare=128.05; $\mathrm{df}=1 ; \mathrm{p}$-value $<0.001$ ). The same differences were observed when the data was broken down by university: Cordoba (chi-square $=42.92$; $\mathrm{df}=1$; $\mathrm{p}$-value $<0.001$; Seville (chi-square=86.94; $\mathrm{df}=1$; $\mathrm{p}$-value $<0.001$ ).

Below we have synthesized the data and presented the results in different tables, taking into account the five areas of the questionnaire that together comprise the set of teaching-related communication skills.

\section{Results for Skills as a Transmitter}

Table 2 in Appendix A shows higher self-evaluation results in this skill among level 3 students $\left(\overline{\boldsymbol{x}}_{3}=3.69\right)$ compared to levels 1 and 2 , which were very similar $\left(\overline{\boldsymbol{x}}_{1}=3.56 ; \overline{\boldsymbol{x}}_{2}=3.53\right)$. Regarding specialty, PE students scored higher as transmitters than ECE students did (3.66 versus 3.53). However, the mean values by university were identical (3.60 for both).

Q-Q Figure 1 shows the means and confidence intervals for the mean (to 95\%) broken down by level and gender. Regarding the evaluation of skill as a transmitter, similar values were observed for males and females at levels 
1 and 2; however, there were differences at level 3, as females scored lower than their male counterparts did.

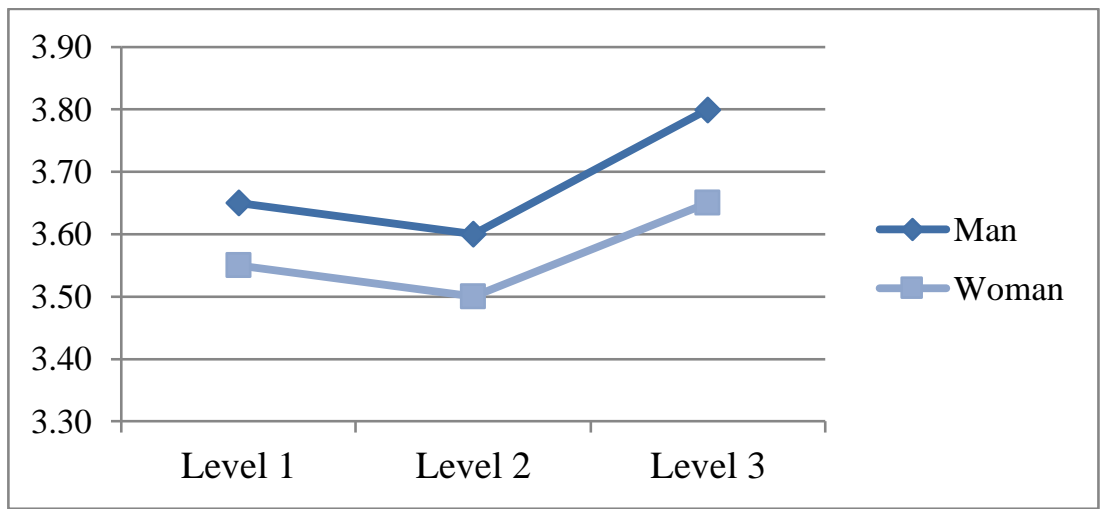

Figure 1. Graph showing the visual contrast between levels and gender with regard to transmission

The MANOVA test showed that evaluation scores were significantly lower for levels 1 and 2 in comparison to level 3. Regarding gender difference, there was a significant relationship to specialty, whereby male $\mathrm{PE}$ students scored higher than their female classmates did $(\mathrm{B}=0.145$; $\mathbf{p}=\mathbf{0 . 0 0 5}$ ). In terms of specialty, although male ECE students scored lower ( $\mathrm{B}=-0.399 ; \mathbf{p}=\mathbf{0 . 0 0 6}$ ) than their PE counterparts, there was no difference amongst the female self-evaluations $(B=-0.043 ; p=0.314)$ (see Table 3 in Annex A).

\section{Results for Skills as a Receiver}

Table 4 in Annex A shows the calculations for both partial and overall measures of central tendency, and reveals a higher evaluation score amongst level 3 students $\left(\overline{\boldsymbol{x}}_{3}=3.85\right)$, followed by that of level 2 students $(\overline{\boldsymbol{x}}$ ${ }_{2}=3.83$ ) and, some way behind, that of level 1 students $\left(\overline{\boldsymbol{x}}_{1}=3.76\right)$. Regarding specialty, PE students scored themselves higher than ECE students for this skill (3.85 and 3.77, respectively). However, the mean values by university were very similar (3.83 for UCO and 3.81 for USE). 
Regarding the scale for the receiver skill, none of the independent variables had a direct effect upon scores, although we did observe potential discrepancies between ECE and PE and level 1 and level 3 students, as shown on the Q-Q normality graph (Figure 2).

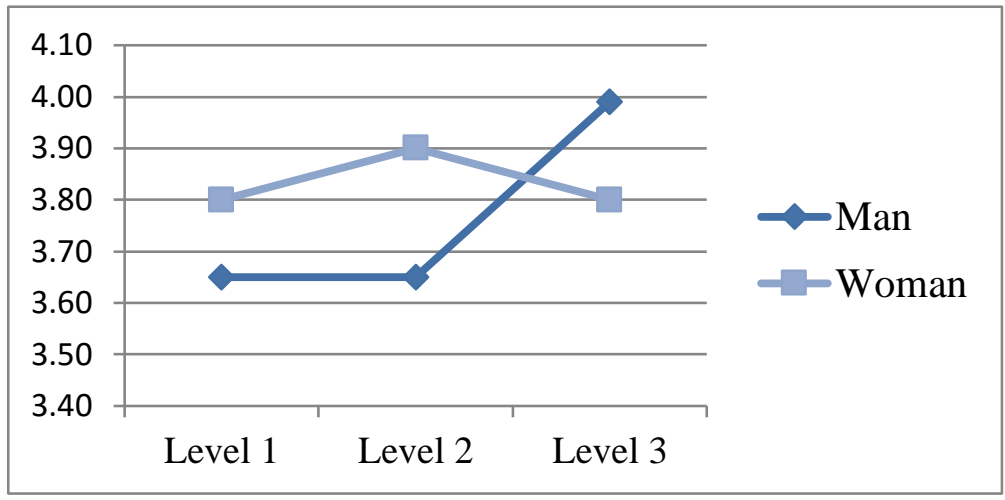

Figure 2. Graph showing the visual contrast between levels and gender with regard to receiver skill

The above variables just about reached just about the proposed level of significance (0.05), as the MANOVA calculation produced a p-value de $\mathbf{0 . 0 6 9}$ for the comparison between PE and ECE and a value of $\mathbf{0 . 0 5 4}$ for that of levels 1 and 3, although they were not enough to be considered different. For the rest of the comparisons, there is a marked absence of significant discrepancy (see Table 5 in Annex A).

\section{Results for Skills as a Classroom Teacher}

Table 6 (Annex A) shows the measures of central tendency for the data extracted from the corresponding questions. The mean of level 3 students is once again higher, meaning they scored higher $\left(\overline{\boldsymbol{x}}_{3}=3.99\right)$. Interestingly, they are followed by level 1 students $\left(\overline{\boldsymbol{x}}_{1}=3.93\right)$, with level 2 picking up the rear $\left(\overline{\boldsymbol{x}}_{2}=3.87\right)$. Regarding specialty, PE and ECE students gave themselves 
similar scores (3.92 versus 3.94, respectively). Likewise, mean values were similar for both universities (3.93 for UCO and 3.95 for USE).

Scores for self-perception as classroom communicators were very similar for levels 2 and 3; however, they were a little higher for female students in level 1 than for their male counterparts, as shown in the Figure 3.

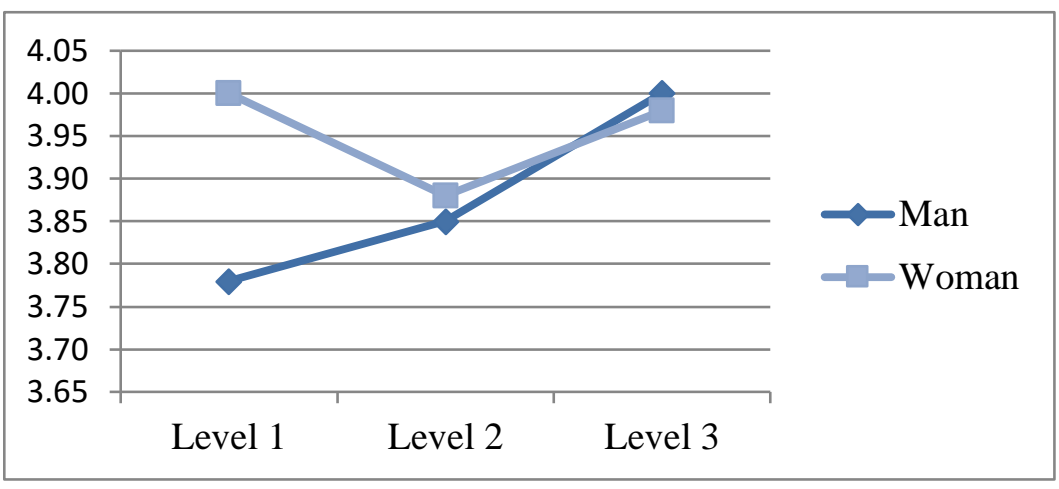

Figure 3. Graph showing the visual contrast between levels and gender with regard to classroom communicators

Significant differences were observed between the level 2 and level 3 scores, with the latter being higher $(\mathrm{B}=-0.129 ; \mathbf{p = 0 . 0 0 8})$. Regarding specialty and gender, the scores for male ECE students were significantly lower $(\mathrm{B}=-0.509 ; \mathbf{p = 0 . 0 0 1})$, while there were no differences among female students in either specialty, nor among PE students of either gender (see Table 7 in Annex A).

\section{Results for Skills as a Participant in Meetings}

The overall scores for this area were extracted from the 12 questions that comprised the scale. Table 8 shows the corresponding quantitative measurements, including the mean, deviation, maximum and minimums, along with the $95 \%$ confidence intervals for the estimated mean. Similar 


\section{Rodríguez et al. - Communication Skills of Future Teachers}

scores were observed for the students at all three levels $\left(\overline{\boldsymbol{x}}_{1}=3.94 ; \overline{\boldsymbol{x}}_{2}=3.98\right.$; $\overline{\boldsymbol{x}}_{3}=3.97$, by level). Regarding specialty, the students' scores were similar to those for the classroom communication skill (3.97 versus 3.95, respectively). Likewise, mean values were similar for both universities (3.97 for UCO and 3.96 for USE) (see Table 8 in Annex A).

Female students at levels 1 and 2 scored higher, while values at level 3 were similar for both genders.

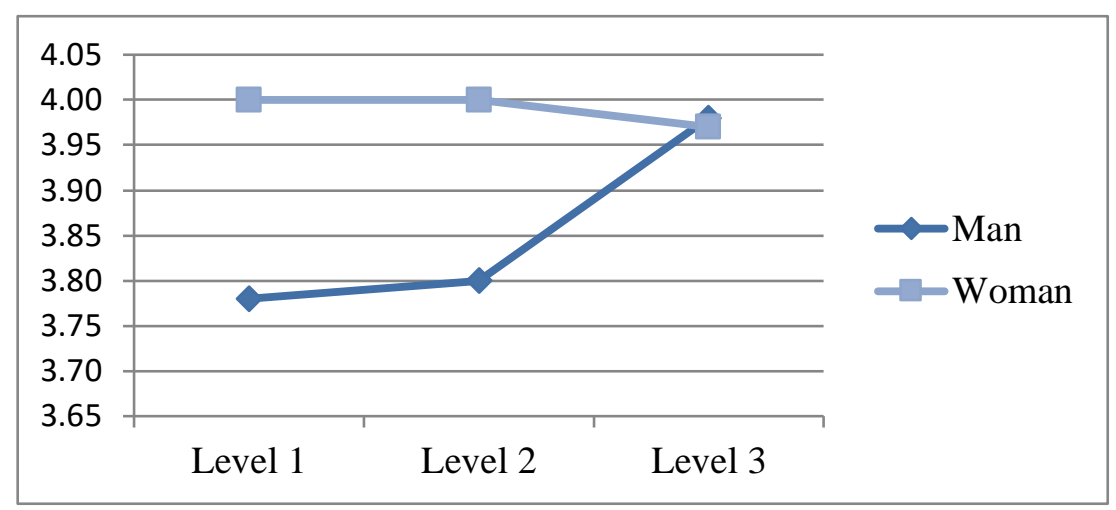

Figure 4. Graph showing the visual contrast between levels and gender with regard to participant in meetings

However, there were differences between genders with regard to specialty; for both ECE and PE, male students scored lower than their female counterparts did ( $B=-0.121 ; \mathbf{p}=\mathbf{0 . 0 4 3}$ ) (see Table 9 in Annex A).

\section{Results for Skills as a Tutor}

The figures in Table 10 (Annex A) show similar evaluation scores among students at all three levels in relation to effective tutoring skills $\left(\overline{\boldsymbol{x}}_{1}=4.00 ; \overline{\boldsymbol{x}}\right.$ ${ }_{2}=3.99 ; \overline{\boldsymbol{x}}_{3}=3.96$, by level). Regarding specialty, the students' scores were similar to those for the classroom communication skill (3.99 versus 3.98, respectively). Likewise, mean values were similar for both universities (3.99 for UCO and 3.98 for USE). 
Females at level 1 scored higher than their male counterparts did, although the values converged at levels 2 and 3, as we can see in Figure 5.

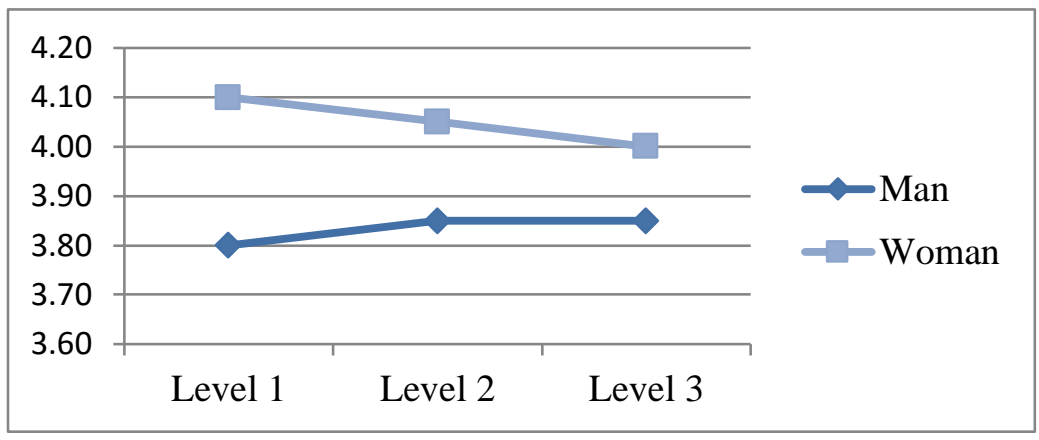

Figure 5. Graph showing the visual contrast between levels and gender with regard to tutor

As occurred in the previous area, there were gender differences for both PE and ECE, with male students in both specialties scoring significantly lower than their female counterparts did $(B=-0.199 ; \mathbf{p}=\mathbf{0 . 0 0 4})$ (see Table 11 in Annex A).

\section{Discussion and Conclusions}

The aim of this study was to analyze future teachers' perception of their own communication skills, while they are still studying. University academics greatly emphasize the need to work on these skills and they admit that the levels of development achieved by students in teachingoriented programs are insufficient, with the exception of skills related to reception and classroom communication (Domingo, Gallego \& Rodríguez, 2013; Gallego \& Rodríguez, 2015).

Thus, it is necessary to investigate how these skills are evaluated by students enrolled in teaching programs at different universities. In general terms, we can assert that students tended to consider that they had sufficient skills: the overall mean was $\overline{\boldsymbol{x}}_{\mathrm{G}}=3.86$, which was broken down into each 


\section{Rodríguez et al. - Communication Skills of Future Teachers}

area of communication as follows: 3.60, 3.81, 3.93, 3.96 and 3.99. The scores for transmission and reception skills were less consistent.

However, in previous studies conducted at the University of Granada (Domingo et al., 2010; Gallego \& Rodríguez, 2013), students generally rated their skills as being insufficient, except in terms of reception skills, which they rated as sufficient. This coincided with the data obtained by Valdemoros \& Lucas (2014) from PE students at the University of La Rioja. Likewise, the study conducted by Conchado \& Carot (2013) confirmed that ICT-based communication, an emerging factor that could become invaluable in teaching-related communication, is a weak area among Spanish university graduates. In that study the capacity to work with families was valued highly, although it was not addressed from a communicative perspective.

Nonetheless, the theoretical model of educational communication has not found practical expression in the students we sampled. In other words, the model is not fully adhered to, given that the variable that should play a fundamentally decisive role in the development of these skills (namely, the level the students were at in their respective degrees) made no difference to any area at all, except in the conventional, generic teaching area of "transmission", where progress through levels 1 to 3 was significant. But even then, the evaluation scores were the lowest of all, suggesting that the progress made is insufficient.

Moreover, in the other areas we either observed no development, or the development was not decisive enough to base conclusions to rech definitive conclusions. Regarding the reception skill, there were certain differences between stage 1 and stage 3 students; however, they were not significant, and even less so between stages 2 and 3. Interestingly, in terms of classroom communication, there were significant differences between stages 2 and 3 but not, counter-intuitively, between 1 and 3, nor between 1 and 2. In the other areas (participation in meetings and tutorial skills) the differences were not significant.

Consequently, progress is very halting, as it does not occur between all stages nor across all skill areas, contrary to expectations. This finding coincides with those of similar studies: although a certain amount of progress in mastery of communication was observed over the course of the degree program (Domingo et al., 2010), at least in the traditional 
communicative areas of transmission and reception (Gallego \& Rodríguez, 2013), this progress was found to be limited and not significant.

Nonetheless, these variables are the ones that show the greatest differentiation with regard to communication skills. Gender, for its part, revealed differences in areas that remained the same for the previous variables: the female students scored significantly higher than their male counterparts did in the areas of participation in meetings and tutoring skills. However, for the other skill areas (transmission, reception and classroom teaching) there were no statistically significant differences. This contrasts with the findings of Valdemoros \& Lucas (2014) with regard to listening skills, as they did observe gender-based differences in favor of the female students.

The students' specialty (ECE or PE) had even less of an impact on their self-perceived communication skills, although they still account for differences in reception skills. Only in the case of male students did we observe a specialty-based difference, in favor of male PE students.

The students' universities (UCO/USE) made no significant difference at all, although we did observe certain discrepancies in relation to the studies conducted at the University of Granada (Domingo et al., 2010; Gallego \& Rodríguez, 2013), where the students only considered themselves sufficiently prepared with regard to reception skills. Nor did we observe any progress in the development of communication skills, as we would have expected.

However, this study has certain limitations, and the results obtained should be interpreted with caution. The nature of a self-evaluation means the research subjects are able to give answers they consider desirable or supposedly correct, rather than answers they have learned or which are genuine. It would be useful to ask knowledge-related questions, not just evaluative ones, with regard to communication skills. Likewise, to study the phenomenon further, the questionnaire instrument should be combined with others (such as in-depth interviews or ethnographic observation) in order to obtain a greater understanding, provided the qualitative focus could be embedded within the quantitative and a paradigm conflict avoided. Last but not least, it would be helpful to expand the sample by including students from other universities in other regions or even other countries, given that, as with any study, it would allow greater comparison of data and help 


\section{Rodríguez et al. - Communication Skills of Future Teachers}

generate inferences of a more generally applicable nature. Additionally, we should complete the information with data from other participants, such as university educators who teach ECE and PE students or non-university educators who have students in their classes for teaching practice. Although this would undoubtedly constitute another line of research, it is one that would be entirely complementary, with the added value of prompting said educators to reflect on the importance of developing their students' communication skills and explore ways in which to do so.

Bearing in mind these limitations and future considerations, we can argue that there is a need to specifically train teaching students in communication skills, by, for example, adding a specific module designed to alert the students to the importance of their role as communicators and develop or perfect their communication skills and strategies. Undoubtedly, this training should be largely practical in nature, as we learn to communicate by communicating. Thus, constant simulation (role-playing) in the classroom and university context, with interchangeable roles based on the different areas of communication described above, and putting these simulations into practice at schools in the form of real teaching experience, must be the basis for developing the communication skills of ECE and PE students. They can be complemented with specific workshops and programs aimed at groups or students whose communication skills are less developed, based on an evaluation conducted using the instrument presented here, given that all the areas of communication described in this study must be taken into account. Any activities implemented by the university must be analyzed from the perspective of its contribution to, among other things, the specific development of the communication skills of its teaching students, given its vital importance to the teaching profession. These actions (Gallego, García \& Rodríguez, 2013) can also be complemented with the addition of other, specific strategies.

\section{References}

Agencia Andaluza de Evaluación Educativa. (AGAEVE). (2010).

Estándares de la práctica profesional docente en Andalucía. Sevilla: AGAEVE. 
Álvarez, M. M., Asensio, I., \& García, J. M. (2013). Deporte y competencias genéricas en la universidad: diseño y validación del “competest". Revista Complutense de Educación, 24(1), 141-163.

Aguilar, A. M. (2013). Competencia comunicativa y norma en los grados de maestro en Educación Primaria. Estudios sobre el Mensaje Periodístico, 19, 25-33. Retrieved from https://revistas.ucm.es/index.php/RCED/article/viewFile/41195/3939 6

Agencia Nacional de Evaluación de la Calidad y Acreditación. (ANECA). (2005). Libro Blanco. Título de grado en Magisterio. Retrieved from http://www.aneca.es/var/media/150404/libroblanco_jun05_magisteri o1.pdf.

Amara, M. E., Karavdic, S., \& Baumann, M. (2013). Students’dropout regarding academic employability skills and satisfaction against University services. In Proceedings International Psychological Applications Conference and Trends, 26-28 April, Madrid: Spain.

Aznar, P., \& Ull, M. A. (2009). La formación de competencias básicas para el desarrollo sostenible: el papel de la Universidad. Revista de Educación, $n^{o}$ extraordinario, 219-237. Retrieved from http://www.revistaeducacion.mec.es/re2009/re2009_10.pdf

Bermúdez, L., \& González, L. (2011). La competencia comunicativa: elemento clave en las organizaciones. Quórum Académico, 18(15), $95-110$. Retrieved from http://www.redalyc.org/articulo.oa?id=199018964006

Camacho, S., \& Sáenz, Ó. (2000). Técnicas de comunicación eficaz para profesores y formadores. Alcoy (Alicante): Marfil.

Camargo, I. M., \& Pardo, C. (2008). Competencias docentes de profesores de pregrado: diseño y validación de un instrumento de evaluación. Universitas Psychologica, 7 (2), 441-455. Retrieved from http://revistas.javeriana.edu.co/index.php/revPsycho/article/view/441

Capitani, P., \& Felicetti, V. L. (2016). Práticas docentes sob o Olhar de Egressos. Multidisciplinary Journal of Educational Research (REMIE), 6(2), 104-126. doi: 10.17583/remie.2016.1665

Castellá, J. M., Comelles, S., Cross, A., \& Vilà, M. (2007). Entender(se) en clase. Las estrategias comunicativas de los docentes bien valorados. Barcelona: Graó. 
106 Rodríguez et al. - Communication Skills of Future Teachers

Comisión Europea. (2008). The European Qualifications Framework $(E Q F)$. Retrieved from http://ec.europa.eu/education/lifelonglearning-policy/doc44_en.htm

Conchado, A., \& Carot, J. M. (2013). Puntos fuertes y débiles en la formación por competencias según los graduados universitarios españoles. Revista de Docencia Universitaria (REDU), 11(1), 429446. doi: 10.4995/redu.2013.5608

Consejo de Europa. (2002). Marco común europeo de referencia para las lenguas: Aprendizaje, Enseñanza, Evaluación. Ministerio de Educación. Instituto Cervantes. Madrid: Anaya.

Consejo Europeo. (2006). Recomendación del Parlamento Europeo y del Consejo de 18 de diciembre de 2006 sobre las competencias clave para el aprendizaje permanente (2006/962/CE). Retrieved from http://eur-

Lex.europa.eu/LexUriServ/LexUriServ.do?uri=OJ:L:2006:394:0010: 0018:ES:PDF

Corredor, J. (2011). Competencias comunicativas: Cátedra esencial en la formación del estudiante universitario. Cuadernos de Lingüística Hispánica, 18, 113-134. Retrieved from

http://revistas.uptc.edu.co/index.php/linguistica_hispanica/article/vie $\mathrm{w} / 434$

Corredor, J., \& Romero, C. A. (2008). Planeación, organización y expresión de un tipo de discurso oral: la exposición. Consideraciones, sugerencias y recomendaciones. Cuadernos de Lingüística Hispánica, 12, 57-76. Retrieved from http://www.redalyc.org/articulo.oa?id=322227542005

Danielson, C. (2011). Competencias docentes: desarrollo, apoyo y evaluación. Santiago de Chile: Programa de Promoción de la Reforma Educativa en América Latina y el Caribe (PREAL), Serie Documentos PREAL núm. 51.

Davies, M. S., \& Taras, M. (2016). A comparison of assessment beliefs of science and education lecturers in a University. Multidisciplinary Journal of Educational Research (REMIE), 6(1), 77-99. doi: 10.17583/remie.2016.1766

Domingo, J., Gallego, J. L., García, I., \& Rodríguez, A. (2010). Competencias comunicativas del maestro en formación. Profesorado. 
Revista sobre currículum y formación del profesorado, 14(2), 303-

323. Retrieved from http://www.ugr.es/ recfpro/rev142COL7.pdf Domingo, J., Gallego, J. L., \& Rodríguez, A. (2013). Percepción del profesorado sobre competencia comunicativa en estudiantes de magisterio. Perfiles Educativos, 35 (142), 54-74. doi:

10.1016/S0185-2698(13)71849-X

Ferreiro, R. F. (2011). Tres vértices del triángulo de las competencias didácticas: teoría, metodología y método. Revista Complutense de Educación, 22(1), 11-23. Retrieved from http://revistas.ucm.es/index.php/RCED/article/view/36564/35398

Field, A. (2005). Discovering Statistics Using SPSS. London: SAGE. Fox, D. J. (1981). El proceso de investigación en educación. Pamplona: Eunsa.

Gallego, J. L., García, A., \& Rodríguez, A. (2013). Cómo escriben los futuros docentes. Estrategias para la mejora. Málaga: Aljibe.

Gallego, J. L., \& Rodríguez, A. (2013). Evaluación de la competencia comunicativa de estudiantes del Magisterio. REVALUE Revista de Evaluación Educativa, 2(1), 110-132. Retrieved from http://revalue.mx/revista/index.php/revalue/article/view/56

Gallego, J. L., \& Rodríguez, A. (2015). Communication Skills Training in Trainee Primary School Teachers in Spain. Journal of Teacher Education for Sustainability, 17(1), 86-98. doi: 10.1515/jtes-20150007

Gauthier, C. (2006). La política sobre formación inicial de docentes en Québec. Revista de Educación, 340, 165-185. Retrieved from http://www.revistaeducacion.mec.es/re340_06.html

Gobierno de Chile-Ministerio de Educación. (2008). Marco para la buena enseñanza $(M B E)$. Santiago de Chile: C\&C Impresores Ltda.

Gobierno de España-Ministerio de Educación. (2009). Marco español de cualificación para la enseñanza superior (MECES). Madrid: Ministerio de Educación.

Grayson, J. (1999). Using surveys to measure "value added" in skills in tour Faculties. The Canadian Journal of Higher Education, 29(1), 111142. Retrieved from https://archive.org/details/ERIC_ED408925 Gutiérrez, S., \& De Pablos, C. (2010). Análisis y evaluación de la gestión por competencias en el ámbito empresarial y su aplicación a la 
108 Rodríguez et al. - Communication Skills of Future Teachers

universidad. Revista Complutense de Educación, 21(2), 323-343. Retrieved from

https://revistas.ucm.es/index.php/RCED/article/viewFile/RCED1010 220323A/15112

Initial Teacher Education. (ITE). (2000). The Standard for Initial Teacher Education in Scotland. Initial Teacher Education (ITE) in Scotland, Quality Assurance Agency for Higher Education. Retrieved from http://www.scotland.gob.uk

Lomas, C., Osorio, A., \& Tusón, A. (2003). Ciencias del Lenguaje, Competencia Comunicativa y Enseñanza de la Lengua. Barcelona: Paidós.

López, J. I. (2011). Un giro copernicano en la enseñanza universitaria: formación por competencias. Revista de Educación, 356, 279-301. Retrieved from http://www.revistaeducacion.mec.es/re356_12.html

Martinet, M. A., Raymond, D., \& Gauthier, C. (2004). Formación de docentes. Orientaciones y competencias profesionales. Québec: Ministère de l'Education.

McMillan, J. H., \& Schumacher, S. (2005). Investigación educativa: una introducción conceptual. Madrid: Pearson Addison Wesley.

Mérida, R. (2013). La controvertida aplicación de las competencias en la formación docente universitaria. Revista de Docencia Universitaria, 11(1), 185-212. doi: 10.4995/redu.2013.5597

Paredes, I., \& Inciarte, A. (2013). Enfoque por competencias. Hacia la integralidad y el desempeño profesional con sentido social y crítico. Omnia, 19(2), 125-138. Retrieved from http://www.redalyc.org/articulo.oa?id=73728678010

Pérez, M., \& Gonçalves, S. (2013). Formación del profesorado en competencias. Profesorado. Revista de currículum y formación del profesorado, 17(3), 3-10. Retrieved from http://www.redalyc.org/pdf/567/56729527001.pdf

Perrenoud, P. (2004). Desarrollar la práctica reflexiva en el oficio de enseñar. Barcelona: Graó.

Scottish Office. (2005). Review of Initial Teacher Education Stage 2:

Review of the Review Group. Retrieved from http://www.scotland.gov.uk/Publications/2005/05/26142053/20548. Accessed November 27 
Stevens, J. P. (2002). Applied multivariate statistics for the social sciences. Mahwah, NJ: Lawrence Erblaum.

Training and Development Agency for Schools. (TDA). (2007). Models Performance Management Policy for Schools. Londres: TDA. UNESCO. (1998). Declaración Mundial sobre Educación Superior en el siglo XXI: Visión Acción y Marco de Acción prioritaria para el cambio y el desarrollo de la Educación Superior. Retrieved from http://www.unesco.org/education/educprog/wche/declaration_spa.ht $\mathrm{m}$.

Valdemoros, M. ${ }^{a}$ A., \& Lucas, B. (2014). Competencias que configuran el perfil docente de primaria. Análisis de la opinión del alumnado de grado en Educación Primaria. Aula Abierta, 42, 53-60. doi: 10.1016/S0210-2773(14)70009-5

Antonio Rodríguez Fuentes is Professor at the Department of Didactics, Universidad de Granada.

María Fernanda Ayllón is Associate professor at the Department of Didactics, Escuela Universitaria la Inmaculada.

José Luis Gallego Ortega is Professor at the Department of Didactics, Universidad de Granada.

Isabel Angustias Gómez Pérez is Associate professor at the Department of Didactics, Escuela Universitaria la Inmaculada.

Contact Address: Campus Universitario de Cartuja C.P. 18071 Granada, Spain.

E-mail: arfuente@ugr.es 
110 Rodríguez et al. - Communication Skills of Future Teachers

\section{ANNEX A}

Table 1.

Distribution of the sample by level, program, university and gender

\begin{tabular}{|c|c|c|c|c|c|c|c|c|}
\hline & & \multirow[b]{2}{*}{ Level } & \multicolumn{2}{|c|}{ Men } & \multicolumn{2}{|c|}{ Women } & \multicolumn{2}{|c|}{ Total } \\
\hline & & & $\mathrm{N}$ & $\%$ & $\mathrm{~N}$ & $\%$ & $\mathrm{~N}$ & $\%$ \\
\hline \multirow[t]{12}{*}{ Cordoba } & ECE & $1^{\circ}$ & 4 & 66,70 & 53 & 42,40 & 57 & 43,50 \\
\hline & & $2^{\circ}$ & 1 & 16,70 & 50 & 40,00 & 51 & 38,90 \\
\hline & & $3^{\circ}$ & 1 & 16,70 & 22 & 17,60 & 23 & 17,60 \\
\hline & Tot: & & 6 & 9.20 & 125 & 55.10 & 131 & 44.90 \\
\hline & PE & $1^{\mathrm{o}}$ & 33 & 55,90 & 34 & 33,30 & 67 & 41,60 \\
\hline & & $2^{\circ}$ & 15 & 25,40 & 30 & 29,40 & 45 & 28,00 \\
\hline & & $3^{\circ}$ & 11 & 18,60 & 38 & 37,30 & 49 & 30,40 \\
\hline & Tot & & 59 & 90.80 & 102 & 44.90 & 161 & 55.10 \\
\hline & Level & $1^{\mathrm{o}}$ & 37 & 56,90 & 87 & 38,30 & 124 & 42,50 \\
\hline & & $2^{\circ}$ & 16 & 24,60 & 80 & 35,20 & 96 & 32,90 \\
\hline & & $3^{\circ}$ & 12 & 18,50 & 60 & 26,40 & 72 & 24,70 \\
\hline & Total & & 65 & 22,30 & 227 & 77,70 & 292 & 100,00 \\
\hline \multirow[t]{12}{*}{ Seville } & $\mathrm{ECE}$ & $1^{\mathrm{o}}$ & 1 & 20,00 & 56 & 30,90 & 57 & 30,60 \\
\hline & & $2^{\circ}$ & 0 & 0,00 & 51 & 28,20 & 51 & 27,40 \\
\hline & & $3^{\circ}$ & 4 & 80,00 & 74 & 40,90 & 78 & 41,90 \\
\hline & Tot: & & 5 & 5.70 & 181 & 62.40 & 186 & 49.20 \\
\hline & PE & $1^{\mathrm{o}}$ & 24 & 28,90 & 25 & 22,90 & 49 & 25,50 \\
\hline & & $2^{\circ}$ & 17 & 20,50 & 28 & 25,70 & 45 & 23,40 \\
\hline & & $3^{\circ}$ & 42 & 50,60 & 56 & 51,40 & 98 & 51,00 \\
\hline & To & & 83 & 94.30 & 109 & 37.60 & 192 & 50.80 \\
\hline & Level & $1^{\mathrm{o}}$ & 25 & 28,40 & 81 & 27,90 & 106 & 28,00 \\
\hline & & $2^{o}$ & 17 & 19,30 & 79 & 27,20 & 96 & 25,40 \\
\hline & & $3^{\circ}$ & 46 & 52,30 & 130 & 44,80 & 176 & 46,60 \\
\hline & Total & & 88 & 23,30 & 290 & 76,70 & 378 & 100,00 \\
\hline \multirow[t]{12}{*}{ Total } & ECE & $1^{\mathrm{o}}$ & 5 & 45,50 & 109 & 35,60 & 114 & 36,00 \\
\hline & & $2^{\circ}$ & 1 & 9,10 & 101 & 33,00 & 102 & 32,20 \\
\hline & & $3^{\circ}$ & 5 & 45,50 & 96 & 31,40 & 101 & 31,90 \\
\hline & Tot: & & 11 & 7.20 & 306 & 59.20 & 317 & 47.30 \\
\hline & $\mathrm{PE}$ & $1^{\circ}$ & 57 & 40,10 & 59 & 28,00 & 116 & 32,90 \\
\hline & & $2^{o}$ & 32 & 22,50 & 58 & 27,50 & 90 & 25,50 \\
\hline & & $3^{\circ}$ & 53 & 37,30 & 94 & 44,50 & 147 & 41,60 \\
\hline & To & & 142 & 92.80 & 211 & 40.80 & 353 & 52.70 \\
\hline & Level & $1^{o}$ & 62 & 40,50 & 168 & 32,50 & 230 & 34,30 \\
\hline & & $2^{o}$ & 33 & 21,60 & 159 & 30,80 & 192 & 28,70 \\
\hline & & $3^{\circ}$ & 58 & 37,90 & 190 & 36,80 & 248 & 37.00 \\
\hline & Total & & 153 & 22,80 & 517 & 77,20 & 670 & 100,00 \\
\hline
\end{tabular}


Table 2.

Description of the scale for skill as a transmitter

\begin{tabular}{|c|c|c|c|c|c|c|c|c|c|c|}
\hline Univ. & Speciality & Level & $\mathrm{N}$ & $\bar{x}$ & $\mathrm{SD}$ & Median & Max. & Min & CI lower & CI upper \\
\hline $\mathrm{C}$ & \multirow{3}{*}{ ECE } & $1^{\circ}$ & 55 & 3,60 & 0,43 & 3,67 & 4,67 & 2,50 & 3,48 & 3,71 \\
\hline $\mathrm{O}$ & & $2^{\circ}$ & 50 & 3,49 & 0,42 & 3,50 & 4,42 & 2,75 & 3,37 & 3,61 \\
\hline $\mathrm{R}$ & & $3^{\circ}$ & 23 & 3,48 & 0,44 & 3,42 & 4,42 & 2,92 & 3,29 & 3,67 \\
\hline D & \multirow[t]{2}{*}{ Total ECE } & & 128 & 3,54 & 0,43 & 3,58 & 4,67 & 2,50 & 3,46 & 3,61 \\
\hline $\mathrm{O}$ & & $1^{\circ}$ & 63 & 3,62 & 0,49 & 3,58 & 4,67 & 2,17 & 3,49 & 3,74 \\
\hline \multirow{4}{*}{$\begin{array}{l}\mathrm{B} \\
\mathrm{A}\end{array}$} & \multirow[t]{2}{*}{$\mathrm{PE}$} & $2^{\circ}$ & 45 & 3,62 & 0,50 & 3,58 & 4,58 & 2,50 & 3,47 & 3,77 \\
\hline & & $3^{\circ}$ & 49 & 3,73 & 0,39 & 3,75 & 4,67 & 2,50 & 3,62 & 3,85 \\
\hline & \multirow[t]{2}{*}{ Total PE } & & 157 & 3,65 & 0,46 & 3,67 & 4,67 & 2,17 & 3,58 & 3,73 \\
\hline & & $1^{\circ}$ & 118 & 3,61 & 0,46 & 3,67 & 4,67 & 2,17 & 3,52 & 3,69 \\
\hline \multirow{2}{*}{\multicolumn{2}{|c|}{ Total levels of UCO }} & $2^{\circ}$ & 95 & 3,55 & 0,46 & 3,50 & 4,58 & 2,50 & 3,46 & 3,65 \\
\hline & & $3^{\circ}$ & 72 & 3,65 & 0,42 & 3,63 & 4,67 & 2,50 & 3,55 & 3,75 \\
\hline \multirow{2}{*}{\multicolumn{2}{|c|}{ TOTAL UCO }} & & 285 & 3,60 & 0,45 & 3,58 & 4,67 & 2,17 & 3,55 & 3,65 \\
\hline & & $1^{\circ}$ & 44 & 3,47 & 0,32 & 3,50 & 3,92 & 2,75 & 3,37 & 3,57 \\
\hline S & \multirow[t]{2}{*}{ ECE } & $2^{\circ}$ & 50 & 3,47 & 0,46 & 3,50 & 4,42 & 2,50 & 3,34 & 3,60 \\
\hline E & & $3^{\circ}$ & 76 & 3,60 & 0,39 & 3,58 & 4,58 & 2,75 & 3,51 & 3,69 \\
\hline V & \multirow[t]{2}{*}{ Total ECE } & & 170 & 3,53 & 0,40 & 3,50 & 4,58 & 2,50 & 3,47 & 3,59 \\
\hline L & & $1^{\circ}$ & 48 & 3,52 & 0,53 & 3,54 & 5,00 & 1,75 & 3,37 & 3,68 \\
\hline $\mathrm{L}$ & \multirow[t]{2}{*}{$\mathrm{PE}$} & $2^{\circ}$ & 40 & 3,54 & 0,39 & 3,50 & 4,17 & 2,67 & 3,41 & 3,66 \\
\hline \multirow[t]{3}{*}{$\mathrm{E}$} & & $3^{\circ}$ & 96 & 3,78 & 0,47 & 3,75 & 5,00 & 2,75 & 3,68 & 3,87 \\
\hline & \multirow[t]{2}{*}{ Total PE } & & 184 & 3,66 & 0,48 & 3,67 & 5,00 & 1,75 & 3,59 & 3,73 \\
\hline & & $1^{\circ}$ & 92 & 3,50 & 0,44 & 3,50 & 5,00 & 1,75 & 3,41 & 3,59 \\
\hline \multirow{2}{*}{\multicolumn{2}{|c|}{ Total levels en USE }} & $2^{\circ}$ & 90 & 3,50 & 0,43 & 3,50 & 4,42 & 2,50 & 3,41 & 3,59 \\
\hline & & $3^{\circ}$ & 172 & 3,70 & 0,45 & 3,67 & 5,00 & 2,75 & 3,63 & 3,77 \\
\hline \multirow{2}{*}{\multicolumn{2}{|c|}{ TOTAL USE }} & & 354 & 3,60 & 0,45 & 3,58 & 5,00 & 1,75 & 3,55 & 3,64 \\
\hline & & $1^{\circ}$ & 99 & 3,54 & 0,39 & 3,58 & 4,67 & 2,50 & 3,46 & 3,62 \\
\hline $\mathrm{T}$ & \multirow[t]{2}{*}{ ECE } & $2^{\circ}$ & 100 & 3,48 & 0,44 & 3,50 & 4,42 & 2,50 & 3,39 & 3,57 \\
\hline $\mathrm{O}$ & & $3^{\circ}$ & 99 & 3,58 & 0,41 & 3,50 & 4,58 & 2,75 & 3,49 & 3,66 \\
\hline $\mathrm{T}$ & \multirow[t]{2}{*}{ TOTAL ECE } & & 298 & 3,53 & 0,41 & 3,58 & 4,67 & 2,50 & 3,48 & 3,58 \\
\hline A & & $1^{\circ}$ & 111 & 3,58 & 0,50 & 3,58 & 5,00 & 1,75 & 3,48 & 3,67 \\
\hline \multirow[t]{4}{*}{$\mathrm{L}$} & \multirow[t]{2}{*}{ PE } & $2^{\circ}$ & 85 & 3,58 & 0,45 & 3,58 & 4,58 & 2,50 & 3,48 & 3,68 \\
\hline & & $3^{\circ}$ & 145 & 3,76 & 0,45 & 3,75 & 5,00 & 2,50 & 3,69 & 3,84 \\
\hline & \multirow[t]{2}{*}{ TOTAL PE } & & 341 & 3,66 & 0,47 & 3,67 & 5,00 & 1,75 & 3,61 & 3,71 \\
\hline & & $1^{\circ}$ & 210 & 3,56 & 0,45 & 3,58 & 5,00 & 1,75 & 3,50 & 3,62 \\
\hline \multirow{2}{*}{\multicolumn{2}{|c|}{ Total levels }} & $2^{\circ}$ & 185 & 3,53 & 0,45 & 3,50 & 4,58 & 2,50 & 3,46 & 3,59 \\
\hline & & $3^{\circ}$ & 244 & 3,69 & 0,44 & 3,67 & 5,00 & 2,50 & 3,63 & 3,74 \\
\hline
\end{tabular}


112 Rodríguez et al. - Communication Skills of Future Teachers

Table 3.

Estimate of multivariate regression parameters for transmission

\begin{tabular}{|c|c|c|c|c|c|c|c|}
\hline \multirow[b]{2}{*}{$\mathrm{T}$} & \multirow[t]{2}{*}{ Independent Variable } & \multicolumn{6}{|c|}{ Estimation of the parameters } \\
\hline & & \multirow[t]{2}{*}{ B } & \multirow[t]{2}{*}{ Standar Error } & \multirow[t]{2}{*}{$\mathrm{t}$} & \multirow[t]{2}{*}{ p-value } & \multicolumn{2}{|c|}{ CI $95 \%$} \\
\hline $\mathrm{R}$ & Parameters & & & & & Lower & Upper \\
\hline A & Constant & 3,69 & 0,04 & & & & \\
\hline $\mathrm{S}$ & Man /Woman & 0,15 & 0,05 & 2,85 & 0,01 & 0,05 & 0,25 \\
\hline $\mathrm{N}$ & $\mathrm{ECE} / \mathrm{PE}$ & $-0,04$ & 0,04 & $-1,01$ & 0,31 & $-0,13$ & 0,04 \\
\hline M & Levels $1^{\circ} / 3^{\circ}$ & $-0,12$ & 0,04 & $-2,81$ & 0,01 & $-0,21$ & $-0,04$ \\
\hline $\mathrm{I}$ & Levels $2^{\circ} / 3^{\circ}$ & $-0,18$ & 0,05 & $-3,90$ & 0,00 & $-0,27$ & $-0,09$ \\
\hline $\mathrm{T}$ & Man*ECE & $-0,40$ & 0,15 & $-2,75$ & 0,01 & $-0,68$ & $-0,11$ \\
\hline $\mathrm{T}$ & & & & & & & \\
\hline $\mathrm{E}$ & & & & & & & \\
\hline $\mathrm{R}$ & & & & & & & \\
\hline
\end{tabular}


REMIE-Multidisciplinary Journal of Educational Research, 7(1) 113

Table 4

Description of the scale for skill as a receiver

\begin{tabular}{|c|c|c|c|c|c|c|c|c|c|c|}
\hline Univ. & Speciality & Level & $\mathrm{N}$ & $\bar{x}$ & $\mathrm{SD}$ & Median & Max. & Min. & CI lower & CI upper \\
\hline \multirow{7}{*}{$\begin{array}{l}\mathrm{C} \\
\mathrm{O} \\
\mathrm{R} \\
\mathrm{D} \\
\mathrm{O} \\
\mathrm{B} \\
\mathrm{A}\end{array}$} & \multirow{3}{*}{ ECE } & $1^{\circ}$ & 57 & 3,77 & 0,49 & 3,80 & 4,80 & 2,80 & 3,64 & 3,90 \\
\hline & & $2^{\circ}$ & 51 & 3,81 & 0,45 & 3,90 & 4,70 & 2,50 & 3,69 & 3,94 \\
\hline & & $3^{\circ}$ & 23 & 3,80 & 0,52 & 3,70 & 4,60 & 2,80 & 3,58 & 4,02 \\
\hline & \multicolumn{2}{|c|}{ Total ECE } & 131 & 3,79 & 0,48 & 3,80 & 4,80 & 2,50 & 3,71 & 3,88 \\
\hline & \multirow{3}{*}{$\mathrm{PE}$} & $1^{\mathrm{o}}$ & 67 & 3,77 & 0,56 & 3,80 & 4,90 & 2,70 & 3,63 & 3,91 \\
\hline & & $2^{\circ}$ & 43 & 3,90 & 0,50 & 3,90 & 5,00 & 2,80 & 3,75 & 4,06 \\
\hline & & $3^{\circ}$ & 49 & 3,93 & 0,54 & 4,00 & 4,90 & 2,20 & 3,78 & 4,09 \\
\hline \multicolumn{3}{|c|}{ Total PE } & 159 & 3,86 & 0,54 & 3,90 & 5,00 & 2,20 & 3,77 & 3,94 \\
\hline \multirow{3}{*}{\multicolumn{2}{|c|}{ Total levels of UCO }} & $1^{\circ}$ & 124 & 3,77 & 0,53 & 3,80 & 4,90 & 2,70 & 3,68 & 3,87 \\
\hline & & $2^{\circ}$ & 94 & 3,85 & 0,47 & 3,90 & 5,00 & 2,50 & 3,76 & 3,95 \\
\hline & & $3^{\circ}$ & 72 & 3,89 & 0,53 & 3,90 & 4,90 & 2,20 & 3,77 & 4,02 \\
\hline \multicolumn{3}{|c|}{ TOTAL UCO } & 290 & 3,83 & 0,51 & 3,90 & 5,00 & 2,20 & 3,77 & 3,89 \\
\hline \multirow{7}{*}{$\begin{array}{l}\text { S } \\
\text { E } \\
\text { V } \\
\text { I } \\
\text { L } \\
\text { L } \\
\text { E }\end{array}$} & \multirow{3}{*}{ ECE } & $1^{\circ}$ & 53 & 3,78 & 0,39 & 3,80 & 4,50 & 3,00 & 3,67 & 3,89 \\
\hline & & $2^{\circ}$ & 51 & 3,76 & 0,52 & 3,80 & 5,00 & 2,60 & 3,62 & 3,91 \\
\hline & & $3^{\circ}$ & 77 & 3,74 & 0,51 & 3,70 & 4,70 & 2,10 & 3,62 & 3,86 \\
\hline & \multicolumn{2}{|c|}{ Total ECE } & 181 & 3,76 & 0,48 & 3,80 & 5,00 & 2,10 & 3,69 & 3,83 \\
\hline & \multirow{3}{*}{$\mathrm{PE}$} & $1^{\circ}$ & 49 & 3,73 & 0,53 & 3,70 & 4,90 & 2,10 & 3,58 & 3,88 \\
\hline & & $2^{\circ}$ & 44 & 3,87 & 0,45 & 3,80 & 4,90 & 3,00 & 3,73 & 4,01 \\
\hline & & $3^{\circ}$ & 97 & 3,91 & 0,48 & 3,90 & 5,00 & 2,80 & 3,81 & 4,00 \\
\hline \multicolumn{3}{|c|}{ Total PE } & 190 & 3,85 & 0,49 & 3,80 & 5,00 & 2,10 & 3,78 & 3,92 \\
\hline \multirow{3}{*}{\multicolumn{2}{|c|}{ Total levels of USE }} & $1^{\mathrm{o}}$ & 102 & 3,76 & 0,47 & 3,80 & 4,90 & 2,10 & 3,66 & 3,85 \\
\hline & & $2^{\circ}$ & 95 & 3,81 & 0,49 & 3,80 & 5,00 & 2,60 & 3,71 & 3,91 \\
\hline & & $3^{\circ}$ & 174 & 3,83 & 0,50 & 3,85 & 5,00 & 2,10 & 3,76 & 3,91 \\
\hline \multirow{2}{*}{\multicolumn{2}{|c|}{ TOTAL USE }} & & 371 & 3,81 & 0,49 & 3,80 & 5,00 & 2,10 & 3,76 & 3,86 \\
\hline & & $1^{\circ}$ & 110 & 3,78 & 0,45 & 3,80 & 4,80 & 2,80 & 3,69 & 3,86 \\
\hline \multirow{8}{*}{$\mathbf{L}$} & \multirow[t]{2}{*}{ ECE } & $2^{\circ}$ & 102 & 3,79 & 0,48 & 3,85 & 5,00 & 2,50 & 3,69 & 3,88 \\
\hline & & $3^{\circ}$ & 100 & 3,75 & 0,51 & 3,70 & 4,70 & 2,10 & 3,65 & 3,86 \\
\hline & \multicolumn{2}{|c|}{ TOTAL ECE } & 312 & 3,77 & 0,48 & 3,80 & 5,00 & 2,10 & 3,72 & 3,83 \\
\hline & \multirow{3}{*}{ PE } & $1^{\circ}$ & 116 & 3,75 & 0,55 & 3,80 & 4,90 & 2,10 & 3,65 & 3,85 \\
\hline & & $2^{o}$ & 87 & 3,89 & 0,47 & 3,90 & 5,00 & 2,80 & 3,79 & 3,99 \\
\hline & & $3^{\circ}$ & 146 & 3,92 & 0,50 & 3,90 & 5,00 & 2,20 & 3,83 & 4,00 \\
\hline & \multicolumn{2}{|c|}{ TOTAL PE } & 349 & 3,85 & 0,51 & 3,90 & 5,00 & 2,10 & 3,80 & 3,91 \\
\hline & & $1^{\circ}$ & 226 & 3,76 & 0,50 & 3,80 & 4,90 & 2,10 & 3,70 & 3,83 \\
\hline \multirow{2}{*}{\multicolumn{2}{|c|}{ Total levels }} & $2^{o}$ & 189 & 3,83 & 0,48 & 3,90 & 5,00 & 2,50 & 3,76 & 3,90 \\
\hline & & $3^{\circ}$ & 246 & 3,85 & 0,51 & 3,90 & 5,00 & 2,10 & 3,79 & 3,91 \\
\hline
\end{tabular}


114 Rodríguez et al. - Communication Skills of Future Teachers

Table 5

Estimate of multivariate regression parameters for receiver skill

\begin{tabular}{|c|c|c|c|c|c|c|c|}
\hline \multirow[b]{2}{*}{$\mathrm{R}$} & \multirow[t]{2}{*}{ Independent Variables } & \multicolumn{6}{|c|}{ Estimation of the parameters } \\
\hline & & $\mathrm{B}$ & Standar Error & $\mathrm{t}$ & p-value & $\mathrm{CIS}$ & $5 \%$ \\
\hline $\mathrm{E}$ & Parameters & & & & & Lower & Upper \\
\hline $\mathrm{C}$ & Constant & 3,90 & 0,04 & & & & \\
\hline $\mathrm{E}$ & Man / oman & $-0,07$ & 0,06 & $-1,12$ & 0,27 & $-0,18$ & 0,05 \\
\hline I & $\mathrm{ECE} / \mathrm{PE}$ & $-0,09$ & 0,05 & $-1,82$ & 0,07 & $-0,18$ & 0,01 \\
\hline $\mathrm{V}$ & Levels $1^{\circ} / 3^{\circ}$ & $-0,10$ & 0,05 & $-1,93$ & 0,06 & $-0,19$ & 0,01 \\
\hline $\mathrm{E}$ & Levels $2^{\circ} / 3^{\circ}$ & 0,01 & 0,05 & 0,10 & 0,92 & $-0,10$ & 0,11 \\
\hline $\mathrm{R}$ & Man*ECE & $-0,26$ & 0,16 & $-1,56$ & 0,12 & $-0,58$ & 0,07 \\
\hline
\end{tabular}


REMIE-Multidisciplinary Journal of Educational Research, 7(1) 115

Table 6

Description of the scale for skill as a classroom teacher

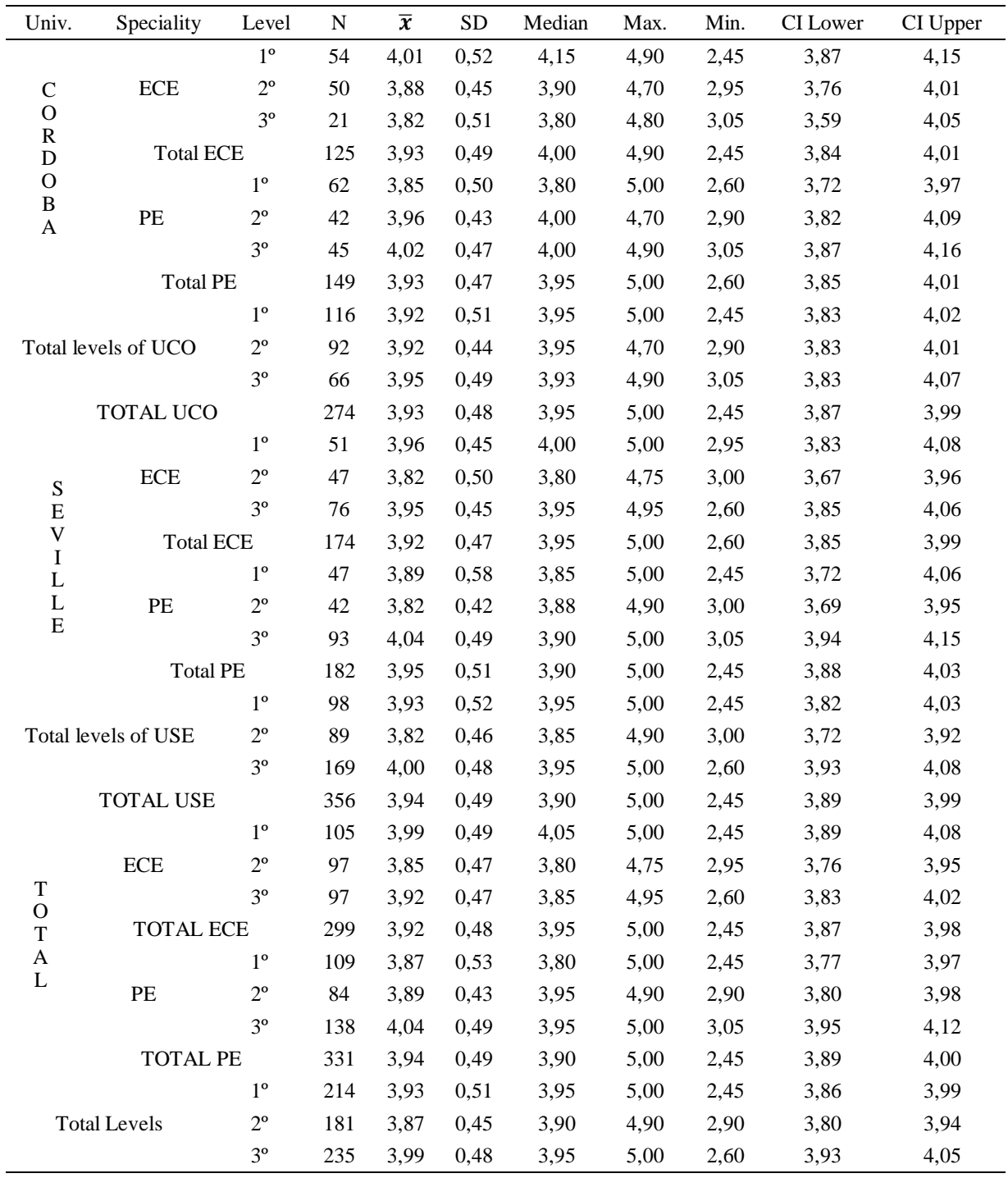


116 Rodríguez et al. - Communication Skills of Future Teachers

\section{Table 7}

Estimate of multivariate regression parameters for classroom communicators

\begin{tabular}{|c|c|c|c|c|c|c|c|}
\hline \multirow{2}{*}{$\begin{array}{l}\mathrm{C} \\
\mathrm{O}\end{array}$} & \multirow[t]{2}{*}{ Independent Variables } & \multicolumn{6}{|c|}{ Estimation of the parameters } \\
\hline & & $\mathrm{B}$ & Standar Error & $\mathrm{t}$ & p-value & $\mathrm{CI}$ & $5 \%$ \\
\hline M & Parameters & & & & & Lower & Upper \\
\hline $\mathrm{U}$ & Constant & 4,02 & 0,04 & & & & \\
\hline $\begin{array}{c}\mathrm{N} \\
\mathrm{I}\end{array}$ & Man/ Woman & $-0,04$ & 0,06 & $-0,67$ & 0,50 & $-0,15$ & 0,07 \\
\hline $\mathrm{C}$ & $\mathrm{ECE} / \mathrm{EP}$ & $-0,01$ & 0,05 & $-0,20$ & 0,84 & $-0,10$ & 0,08 \\
\hline A & Level $1^{\circ} / 3^{\circ}$ & $-0,07$ & 0,05 & $-1,45$ & 0,15 & $-0,16$ & 0,02 \\
\hline $\begin{array}{l}\mathrm{T} \\
\mathrm{O}\end{array}$ & Level $2^{\circ} / 3^{\circ}$ & $-0,13$ & 0,05 & $-2,64$ & 0,01 & $-0,23$ & $-0,03$ \\
\hline $\mathrm{R}$ & Man*ECE & $-0,51$ & 0,16 & $-3,26$ & 0,00 & $-0,82$ & $-0,20$ \\
\hline
\end{tabular}




\section{REMIE-Multidisciplinary Journal of Educational Research, 7(1) 117}

\section{Table 8}

Description of the scale for skill as a participant in meetings

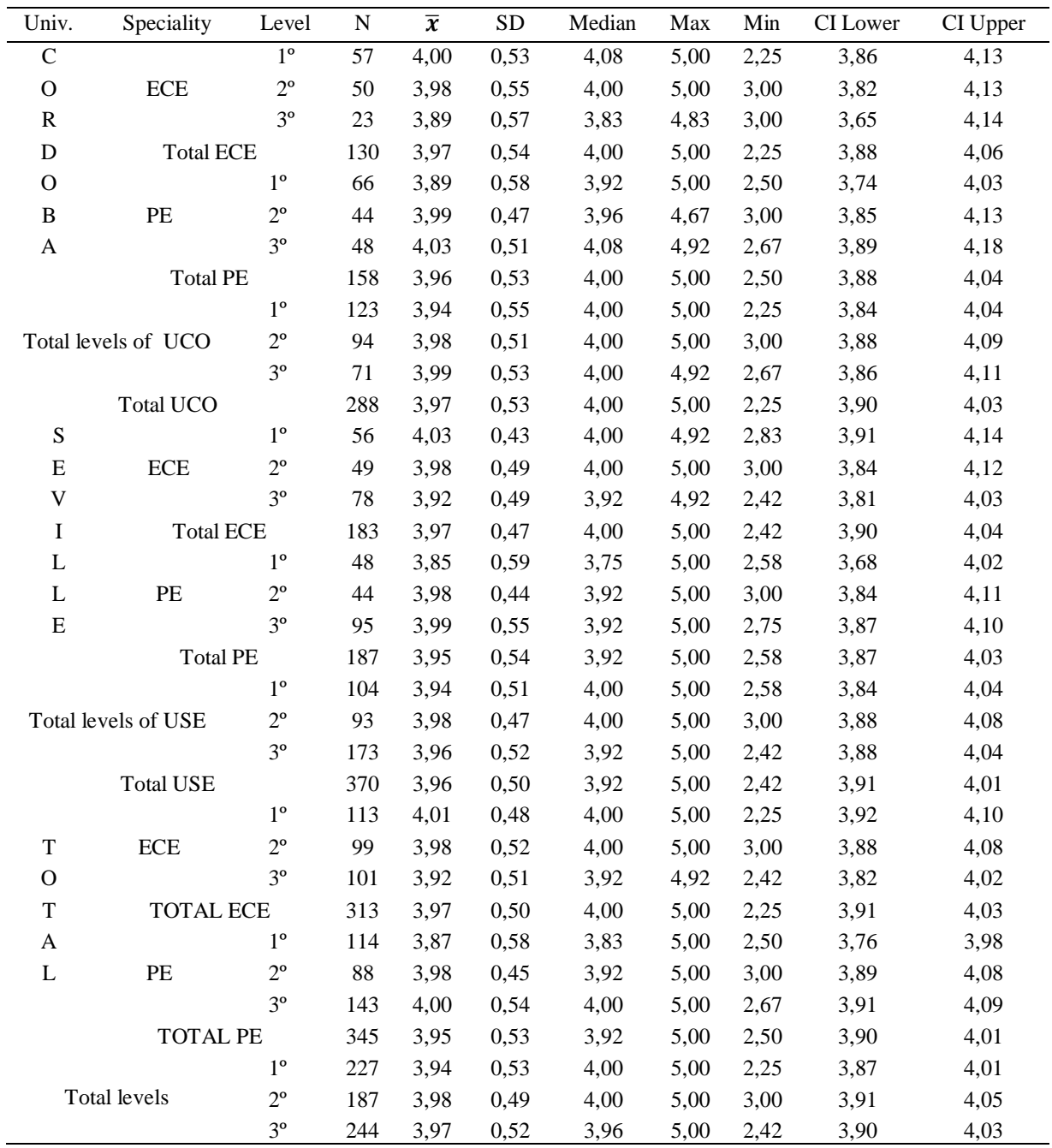


118 Rodríguez et al. - Communication Skills of Future Teachers

Table 9

Estimate of multivariate regression parameters for skill as a participant in meetings

\begin{tabular}{llllllll}
\hline & Independent Variables & \multicolumn{2}{l}{ Estimation of the parameters } \\
\cline { 3 - 8 } $\mathrm{M}$ & & $\mathrm{B}$ & Stand Error & $\mathrm{t}$ & $\mathrm{p}$-value & CI 95\% & \\
$\mathrm{E}$ & Parameters & & & & & Lower & Upper \\
$\mathrm{E}$ & Constant & 4,03 & 0,05 & & & & \\
$\mathrm{~T}$ & Man/Woman & $-0,12$ & 0,06 & $-2,03$ & 0,04 & $-0,24$ & $-0,01$ \\
$\mathrm{I}$ & ECE / PE & $-0,04$ & 0,05 & $-0,75$ & 0,45 & $-0,14$ & 0,06 \\
$\mathrm{~N}$ & Levels 1 / 3 & $-0,03$ & 0,05 & $-0,67$ & 0,51 & $-0,13$ & 0,07 \\
$\mathrm{G}$ & Levels 2 / 3 & 0,01 & 0,05 & 0,15 & 0,88 & $-0,10$ & 0,11 \\
$\mathrm{~S}$ & Man*ECE & $-0,24$ & 0,17 & $-1,44$ & 0,15 & $-0,58$ & 0,09 \\
\hline
\end{tabular}


Table 10

Description of the scale for skill as a tutor

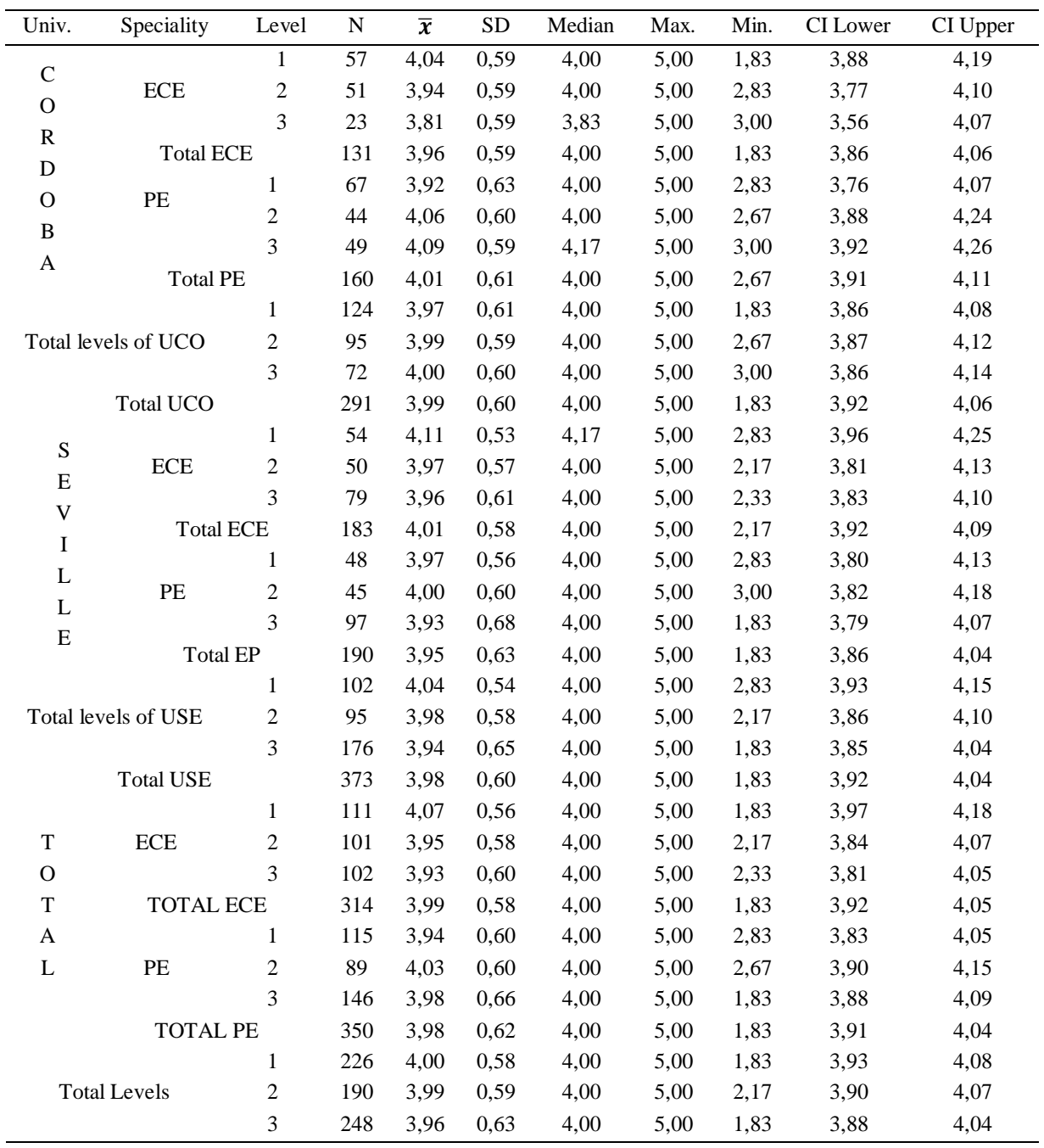


120 Rodríguez et al. - Communication Skills of Future Teachers

Table 11

Estimate of multivariate regression parameters for skill as a tutor

\begin{tabular}{|c|c|c|c|c|c|c|c|}
\hline \multirow[b]{3}{*}{$\mathrm{T}$} & \multirow{3}{*}{$\begin{array}{l}\text { Independent } \\
\text { Variables } \\
\text { Parameters }\end{array}$} & \multicolumn{6}{|c|}{ Estimation of the parameters } \\
\hline & & \multirow[t]{2}{*}{$\mathrm{B}$} & \multirow[t]{2}{*}{ Standar Error } & \multirow[t]{2}{*}{$\mathrm{t}$} & \multirow[t]{2}{*}{ p-value } & \multicolumn{2}{|c|}{ CI $95 \%$} \\
\hline & & & & & & Lower & Upper \\
\hline $\mathrm{U}$ & Constant & 4,07 & 0,05 & & & & \\
\hline $\mathrm{T}$ & Man/Woman & $-0,20$ & 0,07 & $-2,87$ & 0,01 & $-0,34$ & $-0,06$ \\
\hline $\mathrm{O}$ & $\mathrm{ECE} / \mathrm{PE}$ & $-0,06$ & 0,06 & $-1,09$ & 0,27 & $-0,18$ & 0,05 \\
\hline \multirow[t]{3}{*}{$\mathrm{R}$} & Levels $1^{\circ} / 3^{\circ}$ & 0,05 & 0,06 & 0,83 & 0,41 & $-0,07$ & 0,17 \\
\hline & Levels $2^{\circ} / 3^{\circ}$ & $-0,01$ & 0,06 & $-0,09$ & 0,93 & $-0,13$ & 0,12 \\
\hline & Man*ECE & $-0,24$ & 0,20 & $-1,20$ & 0,23 & $-0,62$ & 0,15 \\
\hline
\end{tabular}

